\title{
Peningkatan Kadar Hemoglobin melalui Pemeriksaan dan Pemberian Tablet Fe Terhadap Remaja yang Mengalami Anemia Melalui "Gerakan Jumat Pintar"
}

\author{
Rini Nuraeni ${ }^{1 *}$, Puspa Sari ${ }^{2}$, Neneng Martini ${ }^{2}$, Sri Astuti ${ }^{2}$, Lina Rahmiati ${ }^{2}$ \\ ${ }^{1}$ Program Studi Diploma Kebidanan Fakultas Kedokteran, Universitas Padjadjaran, Jln. Raya Bandung- \\ Sumedang Km. 21 Jatinangor, Sumedang 45363 Jawa Barat, Indonesia \\ ${ }^{2}$ Departemen Ilmu Kesehatan Masyarakat Fakultas Kedokteran, Universitas Padjadjaran, Jln. Raya \\ Bandung-Sumedang Km. 21 Jatinangor, Sumedang 45363 Jawa Barat, Indonesia. \\ *rininuraeni539@gmail.com
}

\section{Submisi: 24 Januari 2019; Penerimaan: 26 Juli 2019}

Kata Kunci: anemia; kadar hemoglobin; tablet Fe; remaja putri.
Keywords: adolescent girls; anemia; hemoglobin; iron supplementation
Abstrak Anemia pada remaja putri dapat berdampak pada penurunan produktivitas kerja dan kemampuan akademik di sekolah serta dalam waktu jangka panjang dapat menyebabkan komplikasi pada kehamilan dan persalinan. Tujuan penelitian ini untuk mengetahui asupan zat besi dan pengaruh pemberian tablet Fe terhadap peningkatan kadar hemoglobin remaja yang mengalami anemia. Penelitian ini menggunakan desain penelitian intervensional dengan rancangan one group pre-test post-test design. Sampel penelitian ini adalah remaja putri. Pengambilan sampel menggunakan teknik total sampling, jumlah sampel 31 responden. Setiap responden mendapatkan tablet Fe setiap hari Jumat melalui "Gerakan Jumat Pintar". Data asupan gizi diperoleh dari kuesioner Food record 3 days. Analisis statistik yang digunakan Uji Wilcoxon. Hasil penelitian menunjukkan setelah diberikannya tablet Fe yang menderita anemia ringan mengalami penurunan dari $42 \%$ menjadi $22,6 \%$, yang menderita anemia sedang mengalami penurunan dari $58 \%$ menjadi $42 \%$. Sedangkan remaja putri yang tidak anemia mengalami peningkatan menjadi 35,4\% Hasil penelitian ini menyimpulkan bahwa terdapat pengaruh pemberian tablet Fe terhadap peningkatan kadar hemoglobin remaja yang mengalami anemia yaitu $1,01 \mathrm{gr} / \mathrm{dl}$.

Abstract Anemia iron deficiency in adolescent girls have an impact to decrease of productivity work and academic ability in school and in long term can lead to complications in pregnancy and childbirth, therefore it is necessary prevention and control of anemia with the provision of iron. The purpose of this research was to determine the intake of iron supplementation and the effectiveness of giving iron oral supplementation to increase levels of adolescent girls hemoglobin. This is an intervensional research with one group pretest posttest design. The Sample in this research is adolescent girls, with total sample 31 respondents. The responden received iron supplementation every Friday, for one month through "Gerakan Jumat Pintar". The intake nutritional data was obtained from food record 3 days. Statisticaly analysis in used is wilcoxon. The result indicated that anemia iron deficiency in adolescent girls is decrease from $42 \%$ to 22,6\%. Adolescent girls suffer from moderate anemia are decrease from $58 \%$ to $42 \%$. Whereas adolescent girls who did not suffer from anemia experienced an increase to 35,4\%. The result of this research concluded that iron supplementation among adolescent girl is the effectiveness of giving iron oral supplementation through "Gerakan Jumat Pintar" to hemoglobin that is increase 1,01 gr/dl. 


\section{PENDAHULUAN}

Anemia merupakan suatu kondisi ketika kadar hemoglobin $(\mathrm{Hb})$ dalam darah tergolong rendah (<12 gr/dl) bagi remaja putri (WHO, 2011). Anemia dapat diakibatkan oleh berbagai penyebab seperti kekurangan asam folat, vitamin B12, vitamin A, dan zat besi. Remaja putri memiliki risiko paling tinggi untuk menderita anemia terutama pada remaja putri usia 13-18 tahun dengan prevalensi 22,7\%. Remaja putri lebih rentan terkena anemia disebabkan oleh beberapa hal, seperti remaja pada masa pertumbuhan membutuhkan zat gizi yang lebih tinggi termasuk zat besi, adanya siklus menstruasi yang menyebabkan remaja putri banyak kehilangan darah, banyaknya remaja putri yang melakukan diet ketat, lebih banyak mengonsumsi makanan nabati yang kandungannya zat besi sedikit, dibandingkan dengan makanan hewani, sehingga kebutuhan zat besi tidak terpenuhi dan asupan gizinya tidak seimbang. Setiap hari manusia kehilangan zat besi 0,6 mg yang diekskresi, khususnya melalui feses (tinja). Remaja putri mengalami haid tiap bulan, dimana kehilangan zat besi 1,25 mg perhari, sehingga kebutuhan zat besi lebih banyak daripada pria. Penyebab paling umum dari anemia secara global adalah anemia defisiensi besi. (Tim Penulis Poltekkes Depkes Jakarta, 2012)

Berdasarkan data dari WHO (2011), dua miliar penduduk dunia mengidap anemia defisiensi zat besi. Sekitar 50\% kasus anemia diakibatkan karena defisiensi besi. Anemia defisiensi besi merupakan suatu kondisi ketika kadar hemoglobin (Hb) dalam darah tergolong rendah. Menurut hasil penelitian yang dilakukan oleh WHO (2015) menyatakan bahwa prevalensi anemia pada remaja putri sebesar $29 \%$. Prevalensi anemia pada remaja putri usia (usia 10-18 tahun) mencapai 41,5\% di negara berkembang. Indonesia merupakan salah satu negara berkembang, prevalensi anemia pada remaja putri di 
Indonesia menurut WHO sebesar 37\% lebih tinggi dari prevalensi anemia di dunia. Jawa barat memiliki angka kejadian anemia pada remaja putri sebesar 51,7\%. (SDKI, 2012)

Menurut Survei Kesehatan Rumah Tangga (2012) menyatakan bahwa prevalensi anemia pada balita sebesar 40,5\%, ibu hamil sebesar 50,5\%, ibu nifas sebesar $45,1 \%$, remaja putri usia 10-18 tahun sebesar 57,1\% dan usia 19-45 tahun sebesar 39,5\%. Remaja putri mempunyai risiko terkena anemia paling tinggi terutama pada masa remaja. Masa remaja merupakan masa yang lebih banyak membutuhkan zat gizi. Remaja membutuhkan asupan gizi yang optimal untuk pertumbuhan dan perkembangannya. Gizi merupakan suatu proses organisme menggunakan makanan yang dikonsumsi secara normal melalui digesti, absorpsi, transportasi penyimpanan, metabolisme dan pengeluaran zat-zat yang tidak digunakan untuk mempertahankan kehidupan pertumbuhan dan menghasilkan energi. (Almatsier, 2009)

Anemia dapat menimbulkan risiko pada remaja putri baik jangka panjang maupun dalam jangka pendek. Dalam jangka pendek anemia dapat menimbulkan keterlambatan pertumbuhan fisik, dan maturitas seksual tertunda. Berdasarkan hasil penelitian yang dilakukan di Sedayu, tentang hubungan kejadian anemia dengan prestasi pada remaja putri didapatkan hasil bahwa terdapat hubungan antara kejadian anemia terhadap prestasi belajar. Hal ini menunjukkan dampak remaja yang mengalami anemia adalah kurangnya konsentrasi sehingga akan memengaruhi prestasi belajar remaja tersebut di kelasnya (Astriandani, 2015). Dampak jangka panjang remaja putri yang mengalami anemia adalah sebagai calon ibu yang nantinya hamil, maka remaja putri tidak akan mampu memenuhi zat-zat gizi bagi dirinya dan juga janin dalam kandungannya yang dapat menyebabkan komplikasi pada kehamilan dan persalinan, risiko kematian maternal, angka prematuritas, BBLR dan angka kematian perinatal. (Akma L, 2016) 
Masalah gizi dapat diatasi bila remaja putri meningkatkan kebutuhan asupan zat besi dalam makanan sehari-hari. Zat besi adalah mineral yang dibutuhkan untuk membentuk sel darah merah. Zat besi juga berfungsi dalam sistem pertahanan tubuh. Setiap tablet besi mengandung $200 \mathrm{mg}$ fero sulfat atau $60 \mathrm{mg}$ besi elemental dan 0,400 asam folat. Salah satu upaya yang telah dilakukan pemerintah untuk menanggulangi masalah anemia pada remaja adalah melalui pemberian suplemen tablet Fe berupa zat besi $\left(60 \mathrm{mg} \mathrm{FeSO}_{4}\right)$ dan asam folat $(0,400 \mathrm{mg})$. Saat ini Peraturan Menteri Kesehatan (Permenkes) tahun 2014 telah menetapkan dosis suplementasi tablet Fe pada WUS (termasuk remaja) adalah 1 tablet/minggu dan ketika menstruasi diberikan setiap hari selama menstruasi. Bagi remaja putri diberikan sebanyak 1 (satu) kali seminggu dan 1 (satu) kali sehari selama haid. (Permenkes, 2014)

Berdasarkan hasil penelitian yang dilakukan oleh Noky (2014) tentang Efektifitas Pemberian Tablet Fe terhadap kadar Hb Siswi SLTPN 1 Donorojo Kecamatan Donorojo Kabupaten Pacitan menyatakan bahwa responden yang telah minum Tablet Fe selama 1 bulan secara teratur didapatkan hasil yang signifikan. Hal ini ditunjukkan dengan adanya kenaikan presentase jumlah siswi SLTP N 1 Donorojo setelah diberikan Tablet Fe didapatkan hasil yang menderita anemia ringan mengalami penurunan dari 102 siswi $(64,56 \%)$ menjadi 70 siswi $(44,30 \%)$ dan yang tidak menderita anemia mengalami kenaikan dari 56 siswi $(35,44 \%)$ menjadi 88 siswi $(55,70 \%)$.

Berdasarkan hasil penelitian yang dilakukan oleh Roos (2016) tentang Survei Anemia pada Remaja Putri di SMA Kecamatan Jatinangor menyatakan bahwa dari 84 responden yang diperiksa terdapat 38 responden yang dinyatakan anemia. Hal ini ditunjukkan dengan status anemia pada remaja putri mencapai 45,2\%. Terdapat proporsi anemia berdasarkan klasifikasi, anemia ringan sebanyak 31,8\%, anemia berat sebanyak 
$2,6 \%$ dan anemia sedang sebanyak $65,8 \%$.

Tujuan dari penelitian ini adalah untuk (1) Mengetahui gambaran asupan zat besi dan zat-zat yang terkait dengan faktor pendorong dan faktor penghambat penyerapan zat besi melalui asupan makanan; (2) Mengetahui peningkatan kadar hemoglobin sebelum dan sesudah diberikan tablet Fe pada remaja yang mengalami anemia melalui "Gerakan Jumat Pintar" pada siswi SMA Plus Al Falah dan SMA Darul Fatwa di Kecamatan Jatinangor; (3) Memberikan informasi pada pihak sekolah mengenai status anemia pada remaja putri SMA Jatinangor sehingga pihak sekolah bisa melakukan tindak lanjut baik secara mandiri maupun bekerja sama dengan pihak terkait seperti Puskesmas dan Dinas Kesehatan untuk penanggulangan masalah anemia pada remaja.

\section{METODE PELAKSANAAN}

Penelitian ini menggunakan desain penelitian intervensional dengan rancangan one group pre-test post-test design. Dalam rancangan ini, observasi dilakukan sebanyak 2 kali yaitu sebelum pemberian tablet $\mathrm{Fe}$, kemudian di observasi kembali setelah pemberian tablet $\mathrm{Fe}$ selama 1 bulan melalui "Gerakan Jumat Pintar". Populasi target dalam penelitian ini adalah remaja putri, sedangkan populasi terjangkau adalah seluruh remaja putri SMA kelas X di SMA Plus AL-Falah dan SMA Darul Fatwa meliputi siswi kelas X di SMA Darul Fatwa sebanyak 50 dan siswi kelas X di SMA Plus Al-Falah sebanyak 15. Setelah dilakukan pemeriksaan kadar hemoglobin dari 65 siswi didapatkan jumlah siswi yang mengalami anemia sebanyak 31 siswi.

Penelitian ini telah mendapatkan persetujuan dari Komite Etik Penelitian Kesehatan Universitas Padjadjaran Fakultas Kedokteran No. 561/UN6.C10/PN/2017. Alur penelitian pada penelitian ini seperti pada Gambar 1. 


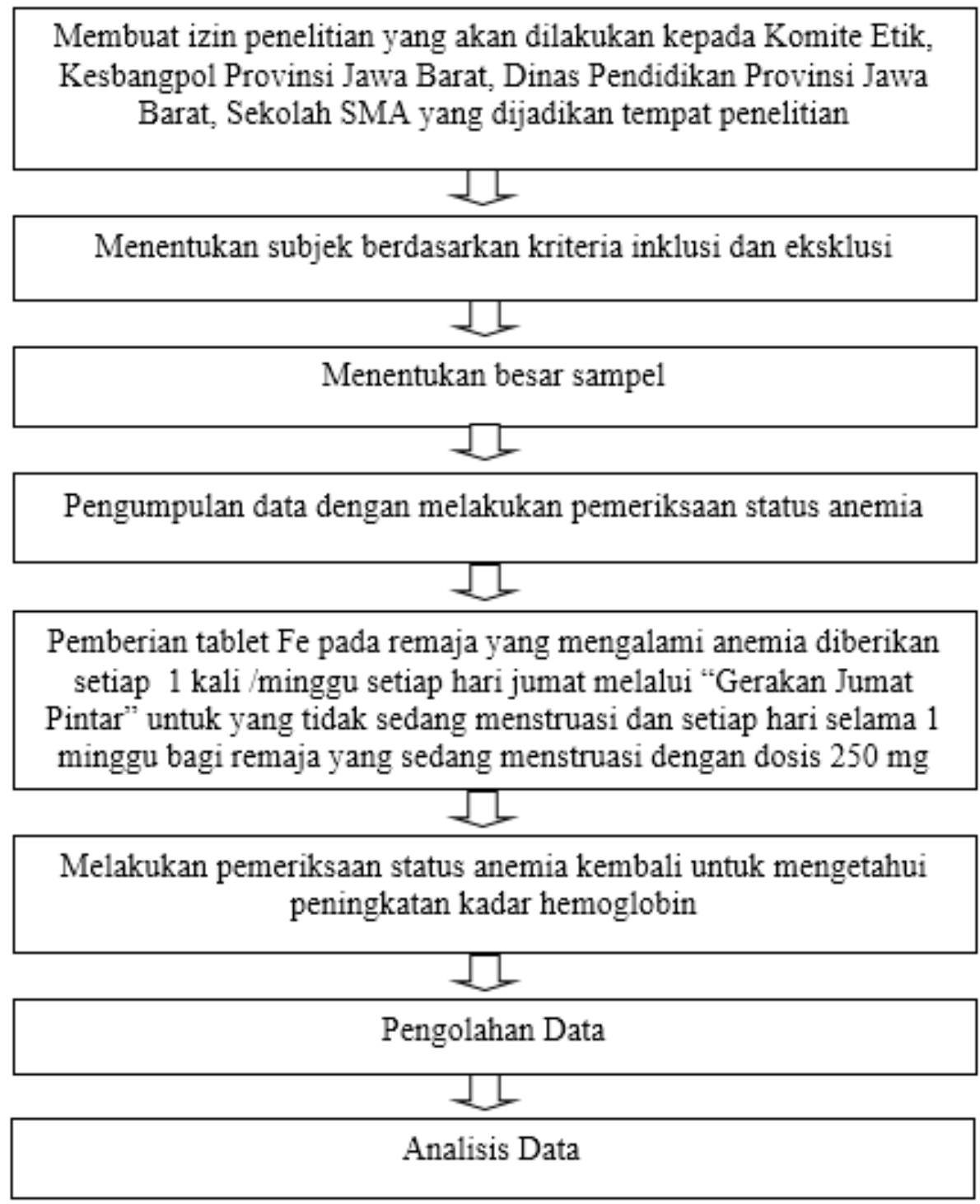

Sumber: Data primer diolah (2017)

Gambar 1. Alur Penelitian 'Gerakan Jumat Pintar'

Teknik pengumpulan data yang dilakukan pada penelitian ini menggunakan beberapa metode. Metode pertama adalah screening kepada 65 orang untuk melihat kadar hemoglobin dengan menggunakan hemoglobinometer digital. Hasil screening dicatat pada lembar form hasil pemeriksaan. Screening ini dilakukan pada tanggal 7-8 Juni 2017 bertempat di SMA Plus Al-Falah dan SMA Darul Fatwa. Hasil screening menunjukkan dari 65 orang yang mengalami anemia sebanyak 31 orang. Selanjutnya, setiap responden 
yang memiliki kadar hemoglobin $<12$ gr/dl akan diberi kuesioner food record 3 days untuk mengetahui pola konsumsi makanan sehari-hari. Hasil analisis asupan pola konsumsi makanan dimasukkan pada aplikasi nutrisurvey untuk dihitung kandungan zat besi pada setiap makanan yang dikonsumsi oleh setiap responden. Hasil dari asupan zat besi tersebut diakumulasikan dan dirata-ratakan. Hasil dari rata-rata kemudian dibandingkan dengan kebutuhan zat besi yang seharusnya dikonsumsi lalu dibandingkan dengan Angka Kecukupan Gizi individu kemudian dikategorikan menjadi kurang, cukup dan lebih.

Selanjutnya, setiap responden yang memiliki kadar hemoglobin $<12$ gr/dl diberikan tablet Fe selama 4 minggu yang dilakukan secara langsung oleh peneliti pada responden dan orangtua dari masing-masing responden tersebut serta diberikannya lembar pemantauan konsumsi tablet Fe. Setiap responden wajib mengisi lembar pemantauan tersebut setelah mengonsumsi tablet Fe nya dengan disaksikan oleh kedua orangtua dari masing-masing responden. Pengukuran Hemoglobin ini dilakukan dua kali yaitu sebelum dan sesudah diberikannya tablet Fe pada remaja yang mengalami anemia dengan menggunakan alat pengukur Hemoglobinometer digital. Pengukuran hemoglobin sesudah diberikan tablet Fe ini dilakukan pada tanggal 10 Juli 2017 bertempat di SMA Plus Al-Falah dan SMA Darul Fatwa.

Data yang telah terkumpul oleh peneliti kemudian dianalisis untuk memberikan arti yang berguna dalam memecahkan masalah dalam penelitian ini. Analisis data yang dilakukan adalah analisis univariat dan analisis bivariat, terlebih dahulu dilakukan uji normalitas pada hasil penelitian dengan Uji shaphiro-wilk karena jumlah sampel $<50$. Data dalam penelitian ini mempunyai distribusi tidak normal dengan nilai $p>0,05$. Untuk mengetahui pengaruh pemberian Tablet Fe terhadap peningkatan kadar hemoglobin 
remaja yang mengalami anemia melalui "Gerakan Jumat Pintar" pada siswi SMA di Kecamatan Jatinangor, maka peneliti menggunakan uji statistik non parametrik, yaitu Uji Wilcoxon. Kemaknaan hasil uji ditentukan berdasarkan nilai $\mathrm{p}<0,05$.

\section{Etika Penelitian}

\section{1) Informed Consent}

Sebelum melakukan penelitian kepada responden, peneliti akan memberikan informed consent kepada responden dalam hal ini adalah siswi SMA kelas X di Jatinangor dan kepada orangtua siswi.

2) Manfaat dan Kerugian

Manfaat dalam penelitian ini khususnya untuk subjek penelitian yaitu siswi putri di SMA Jatinangor adalah siswi tersebut dapat mengetahui status anemianya sehingga dapat segera dilakukan pengobatan yang sesuai. Penelitian dilakukan dengan cara mengambil spesimen darah dari ujung jari subjek dengan cara ditusuk, akan menimbulkan sedikit kesakitan pada responden dan tidak akan menimbulkan risiko yang berbahaya.

3) Menghormati Keadilan

Responden yang mengikuti penelitian ini dilakukan dengan perlakuan yang sama yang selama melakukan pemeriksaan atau selama proses pengambilan sampel berlangsung. 


\section{HASIL DAN PEMBAHASAN}

Survei anemia ini dilakukan kepada 65 responden remaja putri di SMA Plus Al Falah dan SMA Darul Fatwa menyatakan bahwa terdapat 31 responden yang mengalami anemia dengan rata-rata gambaran asupan zat besi dan faktor pendorong penyerapan zat besi berada dalam kategori tingkat konsumsi kurang (Tabel. 1).

Masalah anemia pada remaja putri dapat diatasi bila remaja putri meningkatkan kebutuhan asupan zat besi dalam makanan sehari-hari. Salah satu upaya yang dilakukan untuk menanggulangi masalah anemia pada remaja adalah melalui pemberian suplemen tablet Fe. Pemberian Tablet Fe melalui "Gerakan Jumat Pintar" mendapatkan hasil yaitu adanya perbedaan kenaikan kadar hemoglobin remaja yang mengalami anemia sebelum dan sesudah diberikan Tablet Fe (Tabel. 2).

\subsection{Hasil Penelitian}

Berdasarkan penelitian yang telah dilakukan, diperoleh hasil survei anemia pada remaja putri di SMA Plus Al Falah dan SMA Darul Fatwa. Survei anemia ini dilakukan pada 65 responden dan hasil pengukuran kadar hemoglobin didapatkan bahwa yang mengalami anemia terdapat 31 responden $(47,7 \%)$ dan yang tidak mengalami anemia terdapat 34 responden $(52,3 \%)$.

Tabel. 1 Distribusi Frekuensi Status Anemia Pada Remaja Putri di SMA Plus Al Falah dan SMA Darul Fatwa

\begin{tabular}{ccc}
\hline Status Anemia & Frekuensi (n) & Persentase (\%) \\
\hline Anemia Ringan & 13 & 42 \\
Anemia Sedang & 18 & 58 \\
Anemia Berat & 0 & 0 \\
\hline Total & 31 & 100 \\
\hline
\end{tabular}

Sumber: Data primer diolah (2017) 
Tabel. 2 Gambaran Asupan Zat Besi dan Zat-Zat yang Terkait dengan Faktor Pendorong dan Faktor Penghambat Penyerapan Zat Besi

\begin{tabular}{|c|c|c|c|c|c|c|c|c|c|c|c|c|}
\hline \multirow{2}{*}{$\begin{array}{c}\text { Kategori } \\
\text { Tingkat } \\
\text { konsumsi }\end{array}$} & \multicolumn{2}{|c|}{ Zat Besi } & \multicolumn{2}{|c|}{ Vitamin C } & \multicolumn{2}{|c|}{ Protein } & \multicolumn{2}{|c|}{ Vitamin A } & \multicolumn{2}{|c|}{ Asam folat } & \multicolumn{2}{|c|}{ Zinc } \\
\hline & (n) & $(\%)$ & (n) & $(\%)$ & (n) & $(\%)$ & (n) & $(\%)$ & (n) & $(\%)$ & (n) & $(\%)$ \\
\hline Kurang & 31 & 100 & 31 & 100 & 15 & 48,3 & 22 & 70,9 & 24 & 77,4 & 8 & 25,8 \\
\hline Cukup & 0 & 0 & 0 & 0 & 3 & 9,8 & 9 & 29,1 & 7 & 22,5 & 0 & 0 \\
\hline Lebih & 0 & 0 & 0 & 0 & 13 & 41,9 & 0 & 0 & 0 & 0 & 23 & 74,2 \\
\hline Total & 31 & 100 & 31 & 100 & 31 & 100 & 31 & 100 & 31 & 100 & 31 & 100 \\
\hline
\end{tabular}

Berdasarkan penelitian yang telah dilakukan, Tabel. 2 memberikan gambaran asupan zat besi dan zat-zat yang terkait dengan faktor pendorong dan penghambat penyerapan zat besi. Berdasarkan Tabel. 2, hasil olah data food record 3 days secara keseluruhan bahwa asupan zat besi remaja putri yaitu $100 \%$ berada dalam kategori tingkat konsumsi kurang. Vitamin $\mathrm{C}$ yang berperan sebagai katalisator berada dalam kategori tingkat konsumsi kurang dan zat-zat yang membantu proses pembentukan hemoglobin yaitu protein, vitamin A, asam folat berada dalam kategori tingkat konsumsi kurang. Zinc yang berperan sebagai faktor penghambat penyerapan zat besi berada dalam kategori tingkat konsumsi lebih. Dapat disimpulkan bahwa asupan zat besi remaja putri masih berada dibawah angka kecukupannya. 


\section{Tabel. 3 Kadar Hemoglobin Siswi SMA di Kecamatan Jatinangor Sebelum dan Sesudah diberikan Tablet Fe}

\begin{tabular}{cccrrr}
\hline \multirow{2}{*}{$\begin{array}{c}\text { Kategori kadar } \\
\text { hemoglobin }\end{array}$} & \multicolumn{3}{c}{ Sebelum } & \multicolumn{3}{c}{ Sesudah } & \\
\cline { 2 - 6 } & $(\mathbf{n})$ & $\mathbf{( \% )}$ & $\mathbf{( n )}$ & $\mathbf{( \% )}$ & \\
\hline Anemia ringan & 13 & 42,0 & 7 & 22,6 & 0,000 \\
Anemia sedang & 18 & 58,0 & 13 & 42,0 & \\
Anemia berat & 0 & 0 & 0 & 0 & \\
Normal & 0 & 0 & 11 & 35,4 & \\
\hline Total & 31 & 100 & 31 & 100 & \\
\hline
\end{tabular}

Sumber: Data primer diolah (2017)

Berdasarkan penelitian yang telah dilakukan bahwa terdapat perbedaan kenaikan kadar hemoglobin remaja yang mengalami anemia sebelum dan sesudah diberikan Tablet Fe. Hasil penelitian dan analisis data dengan menggunakan uji Wilcoxon dapat dilihat pada Tabel. 3. Berdasarkan Tabel. 3, didapatkan hasil bahwa kadar Hb siswi SMA di Kecamatan Jatinangor remaja putri yang mengalami anemia ringan sebanyak 13 orang $(42,0 \%)$ sebelum diberikannya tablet Fe dan setelah diberikan tablet Fe menurun menjadi 7 orang $(22,6 \%)$. Remaja putri yang mengalami anemia sedang sebelum diberikan tablet Fe sebanyak 18 orang $(58,0 \%)$ dan menurun menjadi 13 orang $(42,0 \%)$. Sedangkan remaja putri yang tidak menderita anemia mengalami kenaikan menjadi 35,4\% setelah diberikannya tablet Fe.

\subsection{Pembahasan}

Masalah Anemia pada remaja putri terjadi karena kurangnya pengetahuan remaja putri tentang gizi yang kurang memadai, asupan tablet Fe yang kurang, dan pola konsumsi remaja putri lebih banyak mengonsumsi makanan nabati yang kandungan zat besinya 
sedikit, dibandingkan dengan makanan hewani sehingga pemenuhan kebutuhan zat besi tidak terpenuhi. Masa remaja merupakan masa yang lebih banyak membutuhkan zat gizi salah satunya adalah zat besi. Remaja putri harus memperhatikan kebutuhan zat besinya karena kebutuhan zat besi terus meningkat dengan adanya pertumbuhan.

\subsubsection{Gambaran Status Anemia pada Remaja Putri}

Berdasarkan Tabel 1, hasil penelitian menunjukkan bahwa prevalensi anemia pada remaja putri di SMA Plus Al Falah dan SMA Darul Fatwa adalah 47,7\% dengan mayoritas mengalami anemia sedang. Angka prevalensi anemia masih tergolong tinggi apabila dibandingkan dengan dengan data RISKESDAS (2013) sebesar $18,4 \%$. Penelitian ini dapat menunjukkan bahwa anemia pada remaja dapat dikatakan sebagai masalah kesehatan khususnya di SMA Plus Al Falah dan SMA Darul Fatwa.

Hasil penelitian sesuai yang dilakukan oleh Siahaan (2011) terhadap remaja putri di kota Depok dengan prevalensi anemia yaitu 47,53\%. dan dengan penelitian Yamin (2012) di Kab. Kepulauan Selayar dengan prevalensi 68,2\%. Hal ini dapat disebabkan oleh beberapa faktor yaitu kurangnya pengetahuan remaja putri tentang gizi yang kurang memadai, asupan tablet Fe yang kurang, dan pola konsumsi remaja putri lebih banyak mengonsumsi makanan nabati yang kandungan zat besinya sedikit, dibandingkan dengan makanan hewani sehingga pemenuhan kebutuhan zat besi tidak terpenuhi. Remaja lebih banyak ingin tampil langsing, sehingga membatasi asupan makanan termasuk zat besi. Remaja putri harus memperhatikan kebutuhan zat besinya karena kebutuhan zat besi terus meningkat dengan adanya pertumbuhan.

Masalah anemia pada remaja putri dapat berdampak pada penurunan produktivitas kerja ataupun kemampuan akademik di sekolah karena tidak adanya gairah dan 
konsentrasi. Anemia dapat mengganggu pertumbuhan dimana tinggi berat badan menjadi tidak sempurna. Selain itu, daya tahan tubuh akan menurun sehingga mudah terserang penyakit (Morris JL RH, 2015). Jika seorang remaja putri hamil maka bisa berdampak yaitu abortus, melahirkan bayi dengan berat lahir rendah, mengalami penyulit lahirnya bayi karena rahim tidak mampu berkontraksi dengan baik ataupun karena tidak mampu meneran, dan perdarahan setelah persalinan yang berakibat kematian. (Eny K, 2011) Oleh karena itu perlu adanya pencegahan dan penangggulangan anemia pada remaja untuk menurunkan prevalensi anemia pada remaja putri dengan adanya intervensi yaitu pemberian tablet Fe. Remaja putri perlu meminum tablet Fe untuk menanggulangi masalah anemia.

Berdasarkan hasil penelitian yang dilakukan oleh Noky (2014) tentang Efektifitas Pemberian Tablet Fe terhadap kadar Hb Siswi SLTPN 1 Donorojo Kecamatan Donorojo Kabupaten Pacitan menyatakan bahwa responden yang telah minum Tablet Fe selama 1 bulan secara teratur didapatkan hasil yang signifikan. Hal ini ditunjukkan dengan adanya kenaikan presentase jumlah siswi SLTP N 1 Donorojo setelah diberikan Tablet Fe didapatkan hasil yang menderita anemia ringan mengalami penurunan dari 102 siswi $(64,56 \%)$ menjadi 70 siswi $(44,30 \%)$ dan yang tidak menderita anemia mengalami kenaikan dari 56 siswi $(35,44 \%)$ menjadi 88 siswi $(55,70 \%)$.

\subsubsection{Gambaran Asupan Zat Besi dan Zat-Zat yang Terkait dengan Faktor Pendorong} dan Faktor Penghambat Penyerapan Zat Besi

Berdasarkan Tabel 2. bahwa asupan zat besi remaja putri berada dibawah angka kecukupannya dengan rata-rata asupan zat besi yang dikonsumsi oleh 31 responden adalah $11,7 \mathrm{mg}$ berada dalam kategori kurang. Hal ini disebabkan oleh beberapa faktor 
yaitu remaja putri lebih biasa mengonsumsi pangan sumber protein nabati dari kelompok pangan kacang-kacangan dan berbagai olahannya seperti yang merupakan sumber zat besi non heme. Tayel D. and Ezzat, S. (2015) menyatakan penyerapan zat besi non heme lebih rendah dibandingkan dengan sumber zat besi heme dalam bentuk ferro yang lebih mudah di serap oleh dinding sel usus.

Secara keseluruhan subjek pada penelitian ini memiliki tingkat kecukupan vitamin A yang tergolong kurang. Defisiensi vitamin A dapat menyebabkan mobilisasi cadangan Fe di dalam tubuh akan turun. Vitamin A berperan dalam memobilisasi cadangan Fe tubuh untuk dapat mensintesa hemoglobin. Apabila jumlah vitamin A di dalam tubuh kurang, akan memengaruhi status zat besi dengan menghambat penggunaan zat besi pada proses erythropoesis (Damaris N, 2015).

Rata-rata tingkat kecukupan vitamin $\mathrm{C}$ dan asam folat masih tergolong kurang. Vitamin $\mathrm{C}$ berperan membantu proses penyerapan zat besi non heme sehingga jika terjadi kekurangan Vitamin $\mathrm{C}$ maka jumlah zat besi yang diserap akan berkurang dan bisa terjadi anemia. Vitamin $\mathrm{C}$ berperan membantu proses penyerapan zat besi non heme, sehingga jika terjadi kekurangan vitamin $\mathrm{C}$ maka jumlah zat besi yang diserap akan berkurang dan bisa terjadi anemia (Damayanthi, 2015).

Asam folat yang kurang menyebabkan proses pembentukan sel darah merah tidak optimal. Asam folat dalam tubuh berperan dalam proses pembentukan sel darah merah. Ketika makanan sumber asam folat di konsumsi, asam folat yang tercerna kemudian di kirim ke hati. Hati menyimpannya sebagian dan mengirimkan sebagian lainnya ke sumsum tulang. Dalam sumsum tulang inilah asam folat digunakan untuk membuat sel darah merah (Gibson RS, 2007).

Tingkat kecukupan zinc pada penelitian ini tergolong kategori lebih. Zinc 
memengaruhi penyerapan besi. Di dalam darah, zinc juga dapat berikatan dengan transferin (protein pengangkut yang berperan dalam pengangkutan besi di dalam darah). Diet dari makanan seharusnya mengandung porsi zat besi dua kali lebih besar dibandingkan dengan zinc sehingga lebih sedikit transferin yang mengikat zinc. Dengan demikian absorpsi zinc akan lebih rendah. Jika diet menyediakan lebih besar zinc dari pada zat besi maka penyerapan zat besi akan terhambat oleh zinc (Gibson RS, 2007).

Rendahnya absorpsi zat besi di dalam usus dapat disebabkan karena tingginya konsumsi sumber besi non heme dan zat lain seperti tanin pada teh, phosfitin pada kuning telur, asam phytat pada serealia dan kacang-kacangan, asam oksalat pada bayam, serta tingginya mineral lain seperti serat, zinc, mangan, dan kalsium pada makanan (Almatsier S, 2009). Kandungan tanin pada teh dapat menghambat absoprsi zat besi di dalam tubuh terutama apabila teh dikonsumsi bersamaan pada waktu makan akan mengurangi penyerapan zat besi hingga $50 \%$. Hal ini disebabkan zat stimulan yang terkandung dalam kafein dapat meninggalkan kerak pada dinding usus sehingga dapat menghambat rantai produksi enzim dalam pencernaan. Selain itu, terjadi interaksi kuat antara fisikokimia polifenol dengan zat besi dalam usus (Suci N, 2014).

Selain itu, sebagian besar responden (70\%) mengonsumsi teh. Remaja putri yang minum teh mempunyai risiko untuk terkena anemia dibandingkan dengan remaja putri yang tidak minum teh. Hal tersebut dibuktikan dengan penelitian oleh Yamin T (2012) yang mengatakan bahwa minum teh paling tidak satu jam sebelum atau setelah makan akan mengurangi daya serap sel darah terhadap zat besi sebesar $65 \%$.

Besarnya persentase responden yang memiliki tingkat kecukupan zat besi dalam kategori kurang disebabkan oleh kurangnya asupan zat besi dari pangan sumber besi heme yang dapat diperoleh dari pangan hewani. Pangan sumber protein nabati sebagai sumber 
zat besi non heme dari kelompok pangan kacang-kacangan dan olahannya penyerapannya lebih rendah dibandingkan dengan sumber zat besi heme (Mohan J. dan Gumashta, R, 2013). Diperlukan bantuan vitamin C untuk mereduksi zat besi non heme dalam bentuk ferri menjadi ferro agar lebih mudah dalam proses penyerapan ke dalam tubuh. Namun ternyata tingkat kecukupan vitamin $\mathrm{C}$ juga kurang, ditambah dengan jumlah asupan zinc yang lebih besar dibandingkan dengan zat besi mengakibatkan terhambatnya penyerapan zat besi ke dalam tubuh.

Pada penelitian ini subjek penelitian dalam mengonsumsi pangan sumber besi heme (berasal dari kelompok pangan hewani) dalam frekuensi yang lebih rendah jika dibandingkan dengan frekuensi konsumsi pangan sumber besi non heme (berasal dari kelompok pangan nabati). Hal ini dapat dilihat dari rata-rata asupan harian subjek berupa tempe $(80,5 \%)$, tahu (40\%), daun singkong $(60,2 \%)$, susu krim $(87,5 \%)$, dan coklat $(50 \%)$ sedangkan sumber besi hem seperti daging ayam (75,5\%), kambing $(69,2 \%)$, hati ayam $(55,6 \%)$ dikonsumsi secara bulanan sedangkan susu, keju dan telur tidak meningkatkan absorpsi zat besi dalam tubuh sehingga dapat menyebabkan kebutuhan besi subjek kurang dari kebutuhan yang dianjurkan.

Hal ini sejalan dengan penelitian yang dilakukan Kintha (2012) terhadap beda kadar hemoglobin remaja putri anemia setelah pemberian suplemetasi tablet besi folat satu kali dan dua kali per minggu bahwa asupan zat besi masih berada dibawah angka kecukupan yaitu 20,6 mg, protein $50 \mathrm{mg}$ dan vitamin C $50 \mathrm{mg}$. Dapat disimpulkan bahwa asupan zat besi pada remaja putri masih berada dibawah angka kecukupan yang dianjurkan. 


\subsubsection{Kadar Hemoglobin Siswi SMA di Kecamatan Jatinangor Sebelum dan Sesudah}

\section{diberikan Tablet Fe}

Berdasarkan Tabel 3.3, hasil penelitian menunjukkan terdapat peningkatan kadar hemoglobin sebelum dan sesudah diberikannya tablet Fe. Hasil analisa data menggunakan uji Wilcoxon didapatkan nilai $\mathrm{p}<0,05$, yaitu $\mathrm{p}=0,000$, yang dapat disimpulkan bahwa terdapat pengaruh pemberian tablet Fe terhadap peningkatan kadar hemoglobin remaja yang mengalami anemia dengan rata-rata peningkatan kadar hemoglobin sebesar 1,01 gr/dl.

Peningkatan kadar hemoglobin sebelum dan sesudah pemberian tablet Fe ini signifikan karena peningkatan kadar hemoglobin ini dilihat dari jumlah total besi yang dikonsumsi. Perhitungan perkiraan penyerapan zat besi dapat didasarkan pola konsumsi makanan yaitu penyerapan zat besi tinggi (15\%), penyerapan zat besi sedang (10\%), dan penyerapan besi rendah $(5 \%)$.

Kebutuhan zat besi bagi remaja putri SMA kelas X dengan rentang usia 16-17 tahun memiliki kebutuhan zat besi sebesar 26 mg (Permenkes, 2013). Jumlah zat besi yang diabsorpsi di usus sekitar 10-15\% dipengaruhi oleh jenis makanan sumber zat besi, pertumbuhan dan variasi jumlah zat besi yang dikeluarkan melalui menstruasi $0.4-0,5$ $\mathrm{mg} / \mathrm{hari}$, feses $10-15 \mathrm{mg}$, dan keringat/urin 0,5-1 mg sebagai tanda massa eritrosit di dalam darah menurun. Hal ini dikarenakan terjadinya proses pergantian antara sel darah merah yang lama dengan yang baru setelah 120 hari sehingga sedikitnya $1 \%$ dari total besi dalam eritrosit dilepaskan setiap hari sehingga memengaruhi keadaan zat besi di dalam tubuh. Selain itu, terjadinya respon puncak dari retikulosit pada hari ke 5-7 yang diikuti dengan peningkatan kadar hemoglobin sebesar 1-2 gram dalam 4-6 minggu sejak terapi dimulai hingga mencapai normal dan diteruskan kembali selama 2-3 bulan untuk mengisi cadangan besi di dalam tubuh (Thankachan P., Thomas W., Sumithra M., et al. 
2008).

Zat besi dalam hemoglobin dapat keluar dari tubuh melalui pendarahan, menstruasi, dan keringat/urin. Sisanya dibawa ke bagian tubuh lain yang membutuhkan dan disimpan sebagai protein ferritin dan hemosiderin di dalam hati (30\%), sumsum tulang belakang (30\%), dan selebihnya di dalam limfa dan otot (Nawal S, 2014). Suplementasi tablet Fe akan meningkatkan oksigenasi dalam sel menjadi lebih baik, metabolisme meningkat dan fungsi sel akan optimal sehingga daya serap makanan menjadi lebih baik. Oleh karena itu, asupan tablet Fe yang rendah merupakan salah satu penyebab defisiensi besi. Pada saat persediaan berkurang maka lebih banyak besi yang di absorpsi. Besi yang dicerna diubah menjadi besi ferro di dalam lambung dan duodenum oleh transferin plasma ke sumsum tulang untuk sintesis hemoglobin atau ke tempat penyimpanan jaringan (Monica, 2014).

Indikator keberhasilan program pemberian tablet Fe pada penelitian ini adalah dengan cara melihat peningkatan kadar hemoglobin pada remaja yang mengalami anemia. Hal tersebut dapat dilihat pada akhir penelitian ini bahwa terjadi kenaikan kadar gemoglobin sebelum dan sesudah pemberian tablet Fe sebesar 1,01 gr/dl. Peningkatan ini adalah peningkatan kadar hemoglobin yang secara murni peningkatannya dipengaruhi oleh pemberian tablet Fe yang diberikan bukan berasal dari asupan makanan responden. Berdasarkan Tabel 2 bahwa gambaran asupan zat besi dan zat-zat yang terkait dengan faktor pendorong penyerapan zat besi berada dalam kategori tingkat konsumsi kurang dan faktor penghambat penyerapan zat besi yaitu zinc berada dalam kategori tingkat konsumsi lebih. Oleh karena itu, peningkatan kadar hemoglobin pada penelitian ini murni berasal dari tablet Fe yang diberikan kepada responden.

Hasil penelitian sejalan dengan penelitian yang dilakukan oleh Khinta (2012) bahwa terdapat kenaikan kadar hemoglobin sebelum dan setelah intervensi pemberian 
suplementasi tablet besi sebesar 0,63 gr/dl $(\mathrm{t}=-2,092, \mathrm{p}=0,035)$. Dapat disimpulkan bahwa terdapat pengaruh pemberian tablet Fe terhadap peningkatan kadar hemoglobin remaja yang mengalami anemia.

\section{KESIMPULAN}

Penelitian dilaksanakan pada saat menjelang libur kenaikan kelas sehingga tidak semua sekolah bisa dijadikan sampel karena adanya keterbatasan waktu. Penelitian hanya dilakukan selama 1 bulan karena adanya keterbatasan waktu. Diharapkan penelitian selanjutnya dapat dilakukan selama 3 bulan untuk menanggulangi masalah anemia pada remaja. Terdapat peningkatan kadar hemoglobin sebelum dan sesudah diberikan tablet Fe pada remaja yang mengalami anemia melalui Gerakan Jumat Pintar pada siswi SMA Plus Al Falah dan SMA Darul Fatwa di Jatinangor sebesar 1,01 gr/dl.

Berdasarkan hasil penelitian, pembahasan, dan kesimpulan, maka dapat dikemukakan saran sebagai berikut: (1) untuk responden diharapkan dengan adanya pemberian tablet $\mathrm{Fe}$ ini remaja putri mampu mencegah dan mengatasi masalah anemia dengan mengonsumsi tablet Fe secara rutin; (2) untuk pihak Sekolah dihimbau supaya selalu berkoordinasi dengan puskesmas atau instansi terkait agar siswinya dapat diberi tablet Fe dengan dosis $250 \mathrm{mg}$ sehingga terhindar dari anemia; dan (3) untuk peneliti selanjutnya diharapkan peneliti selanjutnya dilakukan penambahan sampel, waktu penelitian yang lebih lama yaitu 3 bulan dan selain diberikannya tablet fe diadakannya promosi kesehatan tentang anemia dan tablet Fe. 


\section{UCAPAN TERIMA KASIH}

Ucapan terima kasih kepada Kesbangpol Provinsi Jawa Barat dan Dinas Pendidikan Provinsi Jawa Barat yang telah memberi izin untuk melakukan penelitian, SMA Plus Al-Falah dan SMA Darul Fatwa sebagai lokasi penelitian, serta siswi kelas X di lokasi penelitian yang berpartisipasi dalam kegiatan penelitian ini.

\section{DAFTAR PUSTAKA}

Akmal L. (2016). Analisis faktor yang berhubungan dengan kejadian anemia gizi pada remaja putri di SMKN 1 Terbanggi Besar Lampung Tangah. Jurnal Kesehatan, 7(3):455-469.

Almatsier S. (2009). Prinsip Dasar Ilmu Gizi. Jakarta: PT Gramedia Pustaka Utama.

Astriandani. (2015). Hubungan kejadian anemia dengan prestasi belajar matematika pada remaja putri kelas 11 di SMAN 1 Sedayu. Yogyakarta

Damayanthi. (2015). Anemia among adolescents in urban field practice area of Rajarajeswari Medical College Bangalore. Al Ameen J Med Sci 8(4): 288-292

Damaris N. (2015). Prevalence and Determinants of Anaemia among Adolescent Girls in Secondary Schools in Ya la Division Siaya District, Kenya. Universal Journal of Food and Nutrition Science 3(1): 1-9

Eny K. (2011). Kesehatan reproduksi remaja dan wanita. Jakarta: Salemba Medika

Gibson RS. (2007). Principal of Nutritional Assesment. Ed ke-2. Oxford: Oxford University Press.

Kintha R. (2012). Beda kadar hemoglobin remaja putri anemia setelah pemberian suplementasi tablet besi folat satu kali dan dua kali per minggu. Semarang: Fakultas Kedokteran Universitas Diponegoro. 
Mohan J. dan Gumashta, R. (2013). Weekly iron folate supplementation in adolescent girls an effective nutritional measure for the management of iron deficiency anemia. Global Journal of Health Science, 5(3):188-194.

Monica. (2014). Iron Deviciency anemia and coqnition in school age girls acomparison of iron and food suplementation strategies. International journal of nutrition, 23: $55-62$

Morris JL RH. (2015). Adolescent sexual and reproductive health: The global challengs International Journal of Gynecology and Obstetrics, 131: S40-S2

Nawal S. (2014). Prevalence of Iron Deficiency Anemia Etiological and Prevention. European Journal of Biology and Medical Science Research, 2(2):55-60

Noky. (2014). Skripsi. Efektifitas Pemberian Tablet Fe terhadap kadar Hb Siswi SLTPN 1 Donorojo Kecamatan Donorojo Kabupaten Pacitan Fakultas Ilmu Kesehatan Universitas Muhammadiyah Surakarta.

Permenkes. (2013). Peraturan Menteri Kesehatan Republik Indonesia No 75 Tahun 2013 tentang Angka Kecukupan Gizi yang dianjurkan bagi Bangsa Indonesia.

Permenkes. (2014). Peraturan Menteri Kesehatan Republik Indonesia Nomor 88 Tahun 2014 tentang standar tablet tambah darah bagi wanita usia subur dan ibu hamil. Indonesia.

RISKESDAS. (2013). Riset Kesehatan Dasar. Jakarta: Badan Penelitian dan Pengembangan Kesehatan Kementerian Kesehatan RI.

Roos A. (2016). Skripsi. Survei Anemia pada Remaja Putri di SMA Kecamatan Jatinangor.

Siahaan N. (2011). Skripsi. Faktor-faktor yang mempengaruhi status anemia pada remaja putri di Wilayah Kota Depok 
Survei Kesehatan Rumah Tangga. (2012). Kementerian Kesehatan Republik Indoensia. Jakarta.

Suci N. (2014). Hubungan tingkat asupan protein, zat besi, vitamin C dan seng dengan kadar hemoglobin pada remaja putri di SMA Batik 1 Surakarta. Surakarta: Fakultas Ilmu Kesehatan Universitas Muhammadiyah Surakarta.

Thankachan P., Thomas W., Sumithra M., et al. (2008). Iron absorption in young indian women: tea interaction of iron status with the influence of the and ascorbic acid. Am. J. Clin Nutr, 87: 881-6. Available from:http://www.ajcn.org/full.pdf

Tayel D. and Ezzat, S. (2015). Anemia and Its Associated Factors among Adolescents in Alexandria, Egypt. International Journal of Health Sciences and Research, 5(10): 260-271.

Tim Penulis Poltekkes Depkes Jakarta. (2012). Kesehatan remaja : problem dan solusinya. Jakarta: Salemba Medika

WHO. (2011). Hemoglobin Concentrations for the diagnosis of anemia and assessment of severity. World Health Organization. Retrieved from: https://www.who.int/vmnis/indicators/haemoglobin/en/

WHO. (2015). The global prevalence of anemia. World Health Organization

Yamin T. (2012). Skripsi. Hubungan pengetahuan asupan gizi dan faktor lain yang menyebabkan anemia di SMA Kabupaten Selayar 